\title{
Taphonomy and palaeopathology of two mysticete whales, upper Miocene Pisco Formation, Peru
}

\author{
Raúl ESPERANTE ${ }^{1^{*}}$ \& Orlando POMA ${ }^{2}$
}

${ }^{1}$ Geoscience Research Institute, Loma Linda, California 92350, USA; resperante@1lu.edu

${ }^{2}$ Universidad Peruana Unión, Carretera Central Km. 19, Ñaña, Lima, Perú; opoma@upeu.edu.pe

* Corresponding author

Esperante, R. \& Poma, O. 2015. Taphonomy and palaeopathology of two mysticete whales, upper Miocene Pisco Formation, Peru. [Tafonomía y paleopatología de dos ballenas mysticete, Formación Pisco, Mioceno superior, Perú]. Spanish Journal of Palaeontology, 30 (1), 1-14.

Manuscript received 12 December 2013

Manuscript accepted 18 July 2014

(C) Sociedad Española de Paleontología ISSN 2255-0550

\section{ABSTRACT}

Two mysticete fossil whales from the upper Miocene of the Pisco Formation in Peru are described that show healed bonefractures in ribs. One specimen is preserved in a tuffaceous, diatomaceous siltstone and the other specimen is preserved in siltstone. Both specimens are well preserved, mostly articulated and almost complete. Shark teeth were found associated with one of the skeletons, but both specimens lack any trace evidence for the activity of macro-scavengers. We suggest that the cause of bone fracture may have been collision with rocky shores, other whales, or large predators. The fact that the rib fractures healed indicates that the whales did not die due to the bone fractures. Sedimentologic and paleontological evidence indicate that they were rapidly buried in the marine platform with well-oxygenated water.

Keywords: Paleopathology, Mysticeti, Pisco Formation, taphonomy, marine mammal.

\section{RESUMEN}

Se describen dos esqueletos de ballenas mysticete del Mioceno superior de la Formación Pisco en el Perú que muestran fracturas en costillas y con evidencia de formación de callo óseo. Un especimen aparece en arcillas tobáceasdiatomáceas y el otro especimen aparece en limos. Ambos esqueletos están casi completos, mayormente articulados y bien conservados. Se encontraron dientes de tiburón asociados con uno de los esqueletos, pero no se hallaron trazas de la actividad de macro-carroñeros en ningún hueso. La causa de la fractura de los huesos puedo haber sido la colisión con costas rocosas, con otras ballenas o con un gran predador. El hecho de que las fracturas de las costillas se curaran indica que las ballenas no murieron debido a dichas fracturas. Las características sedimentológicas y paleontológicas indican que los esqueletos fueron enterrados rápidamente en la plataforma marina en ambiente de aguas bien oxigenadas

Palabras clave: Paleopatología, Mysticeti, Formación Pisco, tafonomía, mamífero marino. 


\section{INTRODUCTION}

Evidence of healed bone-fractures in the fossil record is not uncommon. They have been reported in land vertebrates, including theropod and sauropod dinosaurs, crocodiles, other reptiles, and mammals (e.g., Young \& Cooper, 1927; Sawyer \& Erickson, 1998; Tanke \& Currie, 1998; Molnar, 2001; Katsura 2004; Rothschild \& Molnar, 2005; Cartmill \& Smith, 2009; Lordkipanidze et al., 2013). A significant case is an adult hadrosaur with healed fractures in vertebral spines from the Campanian Dinosaur Park Formation in south-central Alberta, with a bone showing a traumatic fracture resulting in separation of the shaft ends and subsequent callus formation with some reorientation of the two fragments (Straight et al., 2006).

Healed fractures have been found in fossil marine mammals (Table 1). Uhen (2004) reports two specimens of basilosaurus (Dorudonatrox) from the middle to late Eocene of Egypt with pathological features, one a juvenile with three healed broken ribs, and the other an adult with a healed fracture in its right mandible. From the middle Miocene Calvert Formation in Maryland, Dawson \& Gottfried (2002) report an odontocete (Hadrodelphis calvertense) with two ribs showing healing after fracture. Thomas et al. (2008) compile five occurrences of bone fractures in fossil marine mammals, both Mysticeti and Odontoceti, in the northeast Pacific region. Four specimens were from the middle Miocene Round Mountain Silt of the Sharktooth Hill in California, with three ribs, one caudal vertebra with a vertebral epiphysis, showing evidence of healing after fracture. A fifth specimen was from the late Oligocene Pysht Formation in the Olympic Peninsula, Washington. Beatty \& Dooley (2009) report multiple injuries in a mostly complete mysticete skeleton from the Miocene of Virginia, USA, including a complete fracture at approximately half the length of the left mandible, which shows partial new bone growth (callus) but no fusion of the two halves of the mandible. Gerholdt \& Godfrey (2010) report the presence of idiopathic periostitis (i.e., periostitis of unknown cause or origin) in eight fossilized odontocete partial rostra from the Miocene of Maryland, Virginia and Florida, which may have originated from a fracture or trauma. Also from the Miocene Calvert Hills of Maryland a cetacean vertebra with a partially healed compression fracture was reported (Godfrey \& Altman, 2005). Anecdotal observations in the Pisco Formation, Peru, include several cetacean specimens with healed fractures, most of them in ribs (Mario Urbina, pers. comm. 2013). Some of these specimens are stored in the Lima Natural History Museum.

Healed fractures have been also reported in modern cetaceans. Oremland et al. (2010) report a rate of $54 \%$ of individuals with mandibular fractures in the short-finned pilot whale (Globicephala macrorhynchus), studied after two mass strandings in North Carolina, USA, in October 1973. All those fractures presented some degree of healing, including complete callus formation. A systematic autopsy examination of 55 pilot whales (Globicephalamelas) from Newfoundland, east Canada, found three healed rib fractures (Cowan, 1966). Ketten (2005) reports a specimen of male of a Cuvier's beaked whale (Ziphiuscavirostris) with two healed fractures in the right mandible, which show displaced segments joined by replacement bone. A partly healed fracture of a thoracic vertebra is reported by Kompanje (1999) in an adult female of a fin whale (Balaenoptera physalus).

This study expands the record of healed bone-fractures in fossil marine mammals with the description of two mysticete skeletons in shallow marine sediments of the upper Miocene Pisco Formation in Peru (Fig. 1). Each specimen shows callus formation around the fracture line, which indicates recovery after injury. Also preservation of the bones and the sedimentary conditions of burial is discussed.

Table 1. Summary of published occurrences of broken bones in fossil marine mammals. To this date all the fractures have been reported in postcranial skeletal elements.

\begin{tabular}{|c|c|c|c|c|}
\hline Bone & Specimen & Period & Formation and Location & Reference \\
\hline Ribs & Durodonatrox & $\begin{array}{l}\text { Middle to Late } \\
\text { Eocene }\end{array}$ & Egypt & Uhen 2004 \\
\hline Two ribs & Hadrodelphiscal vertense & Middle Miocene & Calvert Fm., Maryland & Dawson and Gottfried 2002 \\
\hline Three ribs & Undetermined cetaceans & Middle Miocene & $\begin{array}{l}\text { Round Mountain Silt, Sharktooth } \\
\text { Hill, California }\end{array}$ & Thomas et al. 2008 \\
\hline Two vertebrae & Undetermined mysticetid & Late Oligocene & $\begin{array}{l}\text { Pysht Fm., Olympic Peninsula, } \\
\text { Washington }\end{array}$ & Thomas et al. 2008 \\
\hline $\begin{array}{l}\text { One caudal } \\
\text { vertebra }\end{array}$ & Undetermined mysticetid & Middle Miocene & $\begin{array}{l}\text { Round Mountain Silt, Sharktooth } \\
\text { Hill, California }\end{array}$ & Thomas et al. 2008 \\
\hline Vertebral epiphysis & Undetermined odontocetid & Middle Miocene & $\begin{array}{l}\text { Round Mountain Silt, Sharktooth } \\
\text { Hill, California }\end{array}$ & Thomas et al. 2008 \\
\hline
\end{tabular}




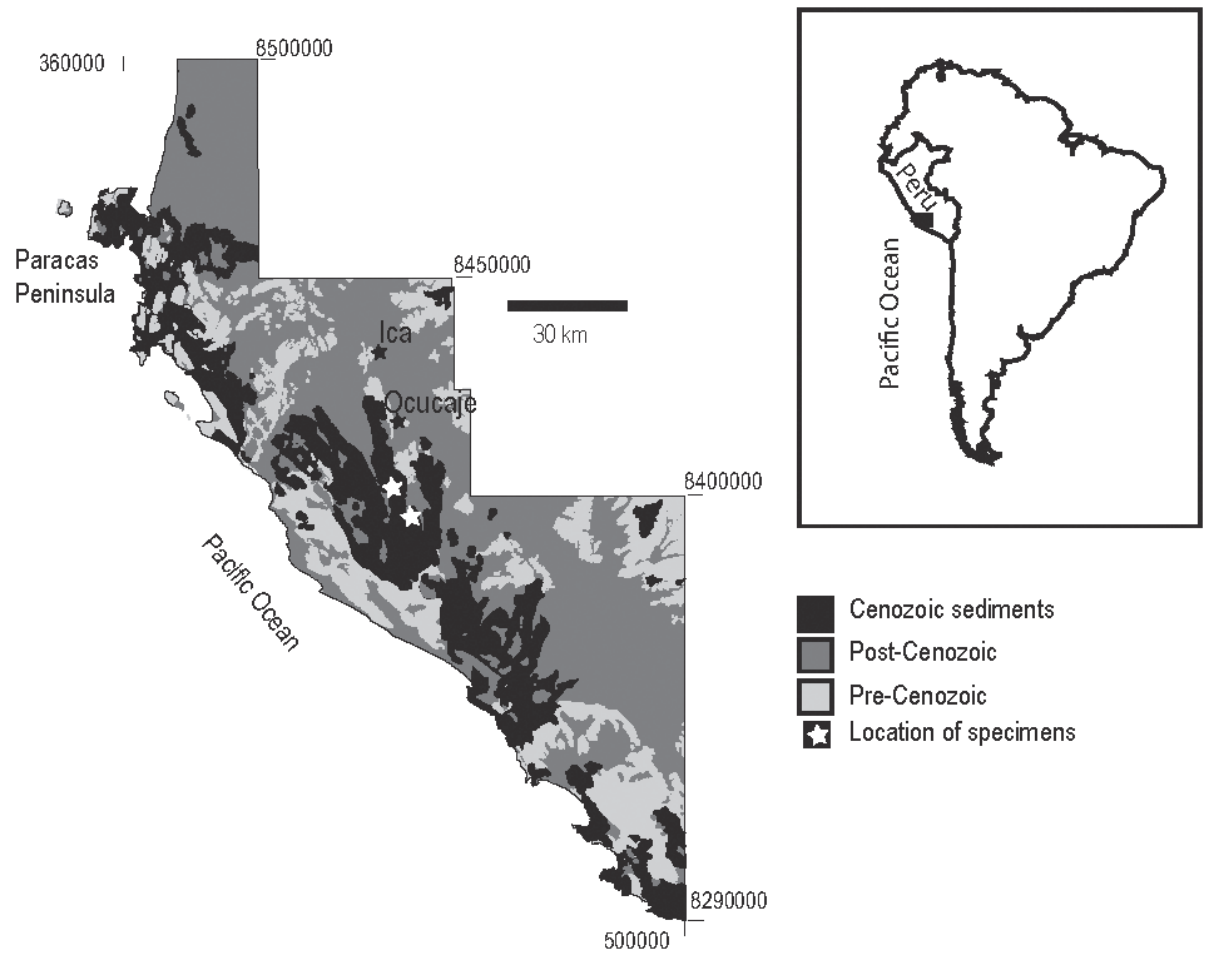

Figure 1. Generalized map of the Pisco Formation in southern Peru. Cenozoic sediments consist of fine sandstones, siltstones, diatomaceous and tuffaceous siltstones and mudstones, and minor carbonates, dolomites, phosphatic pebbles, and conglomerates. The pre-Cenozoic rocks consist of extrusive igneous rocks that may have formed a line of islands during the Cenozoic. Between these islands and the continent, the fine-grained sandstones and siltstones of continental source and the diatomaceous sediments of marine origin accumulated in a sheltered embayment.

\section{GEOLOGIC CONTEXT}

The sediment fill of the Pisco-Ica Basin consists of repeated fining-upward sequences of fine sandstones and siltstones predominant in the lower units, tuffaceous siltstones dominating the middle portion of the infill, and thick, massive layers of tuffaceous, diatomaceous mudstone capping the succession. Minor carbonate-cemented siltstones, thin to very thin phosphate pebble layers, tuffs, and thin to very thin rip-up pebble conglomerate layers occur interspersed throughout the section. The entire sequence has been divided into four formations, which from bottom to top are the Paracas Formation (middle to upper Eocene), the Otuma Formation (Oligocene), the Chilcatay Formation (upper Oligocene to middle Miocene) and the Pisco Formation (middle Miocene to lower Pliocene) (DeVries, 1998). The overall sedimentary succession of the Pisco Formation corresponds to a marine transgression occurring in a shallow embayment or inland sea sheltered by Mesozoic and Paleozoic igneous islands located offshore (de Muizon \& DeVries, 1985) (Fig. 1). Sedimentologic evidence collected during our study suggests that this transgression occurred in several pulses, marked by minor regressive intervals characterized by the deposition of several phosphate and rip-up pebble horizons and by ichnofacies and sedimentary and taphonomic features indicative of shoreface to foreshore settings. There is a general consensus that the Pisco Formation was deposited in relatively shallow water based on diatom and radiolarian assemblages (de Muizon \& DeVries, 1985; Marty et al., 1987; Dunbar et al., 1990; Esperante, 2002), sedimentary structures, and lateral and vertical relationships of the tuffaceous and diatomaceous deposits (Marty, 1989; Carvajal et al., 2000; Carvajal, 2002).

\section{METHODOLOGY}

Two whale fossils showing healed fractures were studied in detail. Whale fossil AM13-1 was found on a slope and mostly exposed on the surface. A single rib with healed fracture was almost fully exposed with the lower surface in situ. Whale FPO8-12 was covered and only the upper part of the skull and the distal end of the skull and mandibles were partially exposed showing some modern weathering. This skeleton was excavated to expose the bones sufficiently to assess degree of preservation on both 
the upper and lateral surfaces, but leaving the bones in situ. Only the caudal portion of the vertebral column remained unearthed because of the thickness of the overlying sediment. The skeleton was covered back up with the same sediment at the end of the study.

Detailed observations were made of each whale specimen, including length and width of skull, numbers of vertebrae, ribs and limbs and relative position of them with respect to the vertebral column and the skull. Degree of articulation and preservation were noted for each bone. The position of the skull, i.e., dorsal-side up or ventral-side up, was noted for both specimens. Careful search for macrofossils was carried out, including shark teeth, mollusks, and physical traces of scavenger activity. Samples of bones and associated sediment were taken for preparation of thin sections. Two trenches perpendicular to the vertebral column were made to expose the relation of the sediment in close association with the bones. Photographs of both specimens were taken. A rib of whale AM13-1 with a healed fracture was removed from the sediment surface and a longitudinal cut with a rock saw was made to show the fracture.

\section{DESCRIPTION OF THE MATERIAL}

\subsection{Whale FP08-12}

\subsubsection{Articulation and preservation}

This skeleton belongs to a single mysticete whale. The total excavated and exposed length of the skeleton is $740 \mathrm{~cm}$ from the distal end of the skull to the lumbar vertebrae; the tail vertebrae was not excavated due to the thickness of the overlying sediment. The growth plates of the vertebrae, humerus, ulna, and radius are fused, indicating that this specimen is an adult. The top surface of some of the bones, including the skull, the two mandibles, and some of the ribs and vertebrae show damage due to modern weathering. The skeleton is almost fully articulated (Fig. 2A). The skull is complete and lies ventral-side up and is aligned with the postcranial skeleton. It is detached from the atlas and slightly displaced from the rest of the cervical vertebrae, but it remains closely associated with the postcranial skeleton (Fig. 2A). The two mandibles are disarticulated and lie on the left side of the skull. The right-side mandible lies parallel to the skull and the left-side mandible, and shows a post-depositional crack due to the weight of the overlying sediment. This crack extends across the entire transverse section of the bone and caused the mandible to lose its anatomical curvature, now lying flat in the sediment. The left mandible preserves its anatomical curvature, with the distal portion slightly overlapping the right mandible, the proximal portion lying on the frontal bone, and the articular end resting on the parietal. The top surface of the skull, the right zygomatic arch, and the two mandibles are heavily weathered due to modern exposure.

Thirty-six vertebrae, including seven cervical vertebrae, were exposed during excavation. Five of the exposed lumbar vertebrae and two of the thoracic vertebrae are articulated; the rest are disarticulated but closely associated and roughly aligned (Figs 2A-B). Seven vertebrae rest on their centra. Most of the vertebrae preserve their neural spines and transverse processes intact and attached to the respective centrum, although some of them show a crack at the connection with the body of the vertebra due to weight of the overlying sediment. The cervical vertebrae are disarticulated and slightly displaced from their original position, but remain closely associated with the occipital area of the skull and the rest of the vertebral column. The atlas is $50 \mathrm{~cm}$ behind the left squamosal, and the axis, lying on its centrum and articulated with the third cervical vertebra (CV3), lies $58 \mathrm{~cm}$ from the occipital condyles. The rest of the cervical vertebrae are buried behind CV3, and their articulation degree was not assessed.

Twelve ribs were present on the right side of the excavated vertebral column. These ribs are roughly parallel to each other. The nine posteriormost ribs slightly overlap each other, whereas the three anterior ribs are aligned parallel to each other and resting on the scapula, humerus, ulna, and radius. These ribs are nearly in articulation with the thoracic vertebrae. Nine ribs were excavated on the left side of the vertebral column. One of them lies underneath the cranium and its articular end is touching the left occipital condyle. The other eight ribs are clustered and in association with each other, not in anatomical articulation, underneath the vertebral column with only their distal ends protruding off the ground (Fig. 2A).

The two limbs are partially preserved on each side of the vertebral column. The flipper on the right side is in anatomical position, lying under three ribs, with scapula humerus, ulna, and radius articulated. Carpals, metacarpals, and phalanges are missing. The flipper on the left side is more complete, including scapula, humerus, ulna, radius and several carpals, and metacarpals (Fig. 2C). The humerus is disarticulated from the scapula and lies on the distal edge of the scapula. Humerus, radius, ulna, carpals, and one excavated metacarpal are articulated. Four disarticulated phalanges were found associated with this limb. Other metacarpals and phalanges might be buried in the sediment.

Most bones show transverse and longitudinal compaction fractures (Figs 2A, C, G). Except for those postdepositional fractures and recent weathering, all the bones are intact and well preserved. Some bones show 

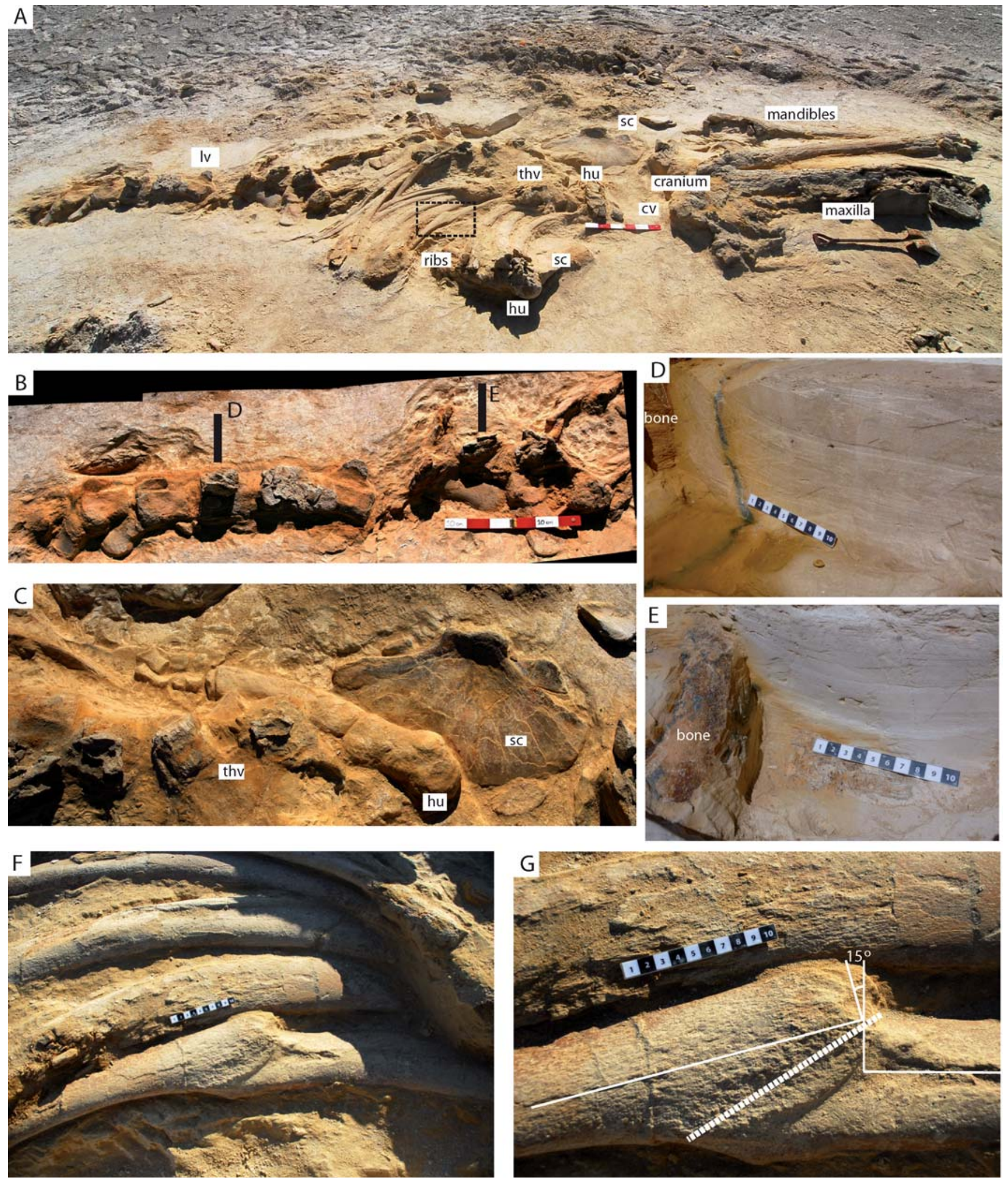

Figure 2. Whale fossil FP08-12. A) General view of the skeleton. The top surfaces of several bones, including the cranium, mandibles and some vertebrae show limited weathering. The skull is ventral-side up. The dotted box indicates the healed broken rib, which is shown in $\mathbf{F}$ and G. Scale bar is $60 \mathrm{~cm}$. B) Partially disarticulated lumbar vertebrae. The bones are only slightly displaced from their anatomical position, which might be due to displacement caused by the collapse after the soft tissue decayed. The two black lines indicate the trenches excavated to show the relationship of associated sediment to the bones (shown in $\mathbf{D}$ and $\mathbf{E}$ ). Scale bar is $60 \mathrm{~cm}$. C) Detail of five thoracic vertebrae partially exposed, and the left-side limb, with scapula humerus, radius and carpals. D-E) Cross section of the sediment associated to the bones. Note that the thin laminations run up against the bone. No sedimentary structure indicating deformation of the sediment due to a sinking carcass is observed. Scale bar is $10 \mathrm{~cm}$. F-G) Detail of the healed fracture (dotted line) of the rib. The thick lines along the shaft indicate the long axis. Scale bar is $10 \mathrm{~cm}$. Note: $\mathrm{cv}=$ cervical vertebrae; hu= humerus; $1 \mathrm{v}=$ lumbar vertebrae; $\mathrm{sc}=\mathrm{scapula}$, thv $=$ thoracic vertebrae 
postburial deformation, including the left mandible, five ribs on the right side, and the scapula of the left side. None of the bones show evidence of preburial weathering, abrasion, corrosion, fragmentation, predation or scavenging. Both the upper and lower surfaces of the bones show an excellent degree of preservation. Three small shark teeth were found associated with the skeleton, but no shark tooth marks or any other evidence of predation of scavenging was observed in the bones.

\subsubsection{Sedimentology}

The specimen is preserved in a single thick layer of homogeneous, tuffaceous, diatomaceous siltstone. This unit shows thick lenticular laminations, but not with alternation of dark and light laminae as in the Monterey Formation diatomite (Govean \& Garrison,1981). Sediment associated with the bones is more indurated and cemented than sediment a few centimeters away from the skeleton. There is a very thin rim of black sediment around the skeleton and in between some closely associated bones (e.g., vertebrae). Analysis of this black rim indicates a high content of iron and manganese oxides. Sediment exposed on two trenches dug out transversally to the vertebral column does not show any structure or deformation due to the collapse of the sediment around the bones. There is a lack of visible macro-sedimentary structures except for laminations, and sediment is not deformed either above or underneath the bones but the horizontal lenticular laminations terminate against the surface of the bones, with a slight folding occurring above the bones, indicating that sediments accumulated adapting to the overall shape of the skeleton (Figs 2D-E). These laminations are very thin lenses of diatomite that thin out laterally. Fish scales, clustered in small packets, are abundant in the sediment. No evidence of associated invertebrate fauna on the bones or in the associated sediment was found.

\subsubsection{Paleopathology}

One of the ribs of this skeleton shows evidence of paleopathology, consisting of a healed fracture. It consists of a clear, snap break, with an angle $15^{\circ}$ oblique to the long axis of the shaft (Figs 2A, F-G). The fracture was healed during the lifetime of the whale, indicated by the formation of a callus, but the bones didn't realign correctly.

\subsection{Whale AM13-1}

\subsubsection{Articulation and preservation}

This specimen consists of a nearly complete skeleton of a mysticete whale partially exposed on aslope (Fig. 3A). The partial suture of the vertebral epiphyses indicates that the specimen is a subadult. The exposed surfaces of the bones are weathered, except on the ribs, which, aside from postexposure fragmentation, lack evidence of weathering. The skull is dorsal-side up and complete (Figs 3C-D). The right mandible is disarticulated from the skull, with its proximal end lying beneath the parietal bone and thezygomatic arch. The articulating end of the left mandible is displaced 12 $\mathrm{cm}$ from the skull but its distal end remains in anatomical position next to the distal end of the maxilla (Figs 3C-D). Cervical vertebrae are disarticulated and detached from the occipital condyles. Thoracic vertebrae are disarticulated but closely associated. On the left side, where the bones are still buried, the heads (articular ends) of ten ribs are in close proximity to the articulation point with the thoracic vertebrae; possibly more ribs are buried. Sediment on the right side of the skeleton is partially removed by erosion, thus exposing the ribs and the vertebral processes, which are fragmented in multiple clean pieces that remain associated and roughly aligned (Fig. 3E). Lumbar and tail vertebrae are buried in dorsal-side up position and fully articulated; their neural arches removed due to erosion, with the fragments lying on the slope. Limb bones were not found. On the right side of the skeleton, the removal of much sediment by erosion might have removed the limb bones. However, because the ribs on that side still occur, though fragmented (Figs $3 \mathrm{C}, \mathrm{E}$ ), it is possible that the right-side limb bones are buried on the opposite side or below the vertebral column. The left limb also might be buried under the ribs.

All the bones are intact and well preserved, except for recent weathering of the exposed surfaces and the occurrence of transverse and longitudinal postdepositional compaction fractures in the skull, mandibles, and ribs. None of the bones shows evidence of pre-burial

Figure 3. Whale fossil AM13-1. A-B) Stratigraphic setting of the skeleton. The bones occur within a very thick layer of very fine sandstone with high content in volcanic ash. C) The partially exposed skeleton. Box indicates the position of the rib with the healed fracture. D) Detail of skull and mandibles. E) Detail of ribs and articulated vertebral column. The ribs are broken up due to modern weathering but the bone surface shows excellent preservation. Scale bar is $10 \mathrm{~cm}$. F) Cross section of the associated sediment next to the vertebral column. Scale in $\mathrm{cm}$. G-I) Sedimentary structures in the layer with the whale bones. These structures include ripple-cross lamination, gutter casts, channel, scour-and-fill and wave ripples. Scale bar in $\mathrm{cm}$. E-G) Rib with healed fracture. The shaft of the rib shows a $21 \%$ displacement, calculated as a/b $(\mathrm{a}=9 \mathrm{~mm}, \mathrm{~b}=43 \mathrm{~mm})$. Angularity is $15 \%$. Scale bar in B, E, F, and G is $10 \mathrm{~cm}$, and in D in $1 \mathrm{~m}$. 


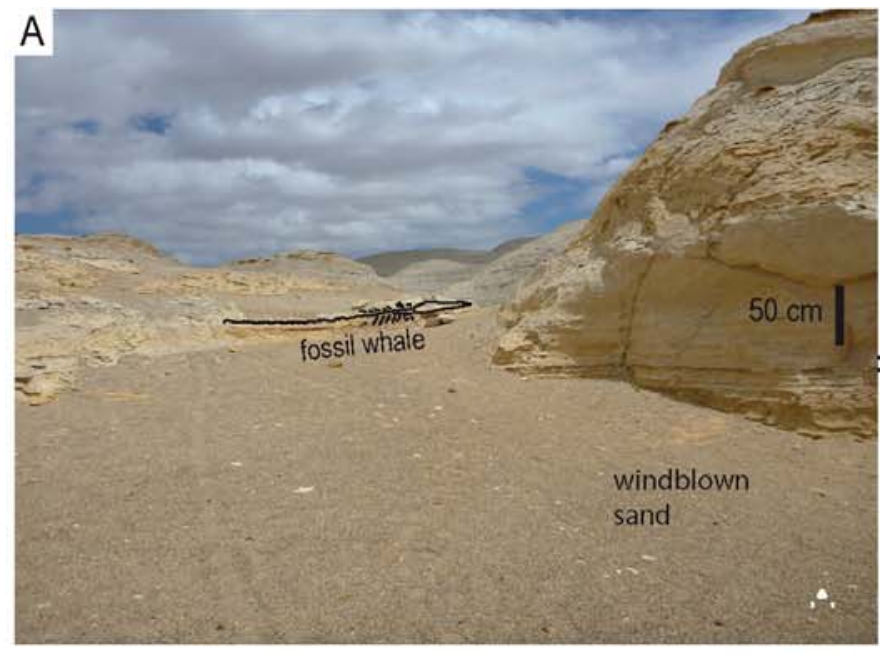

B momy thickness
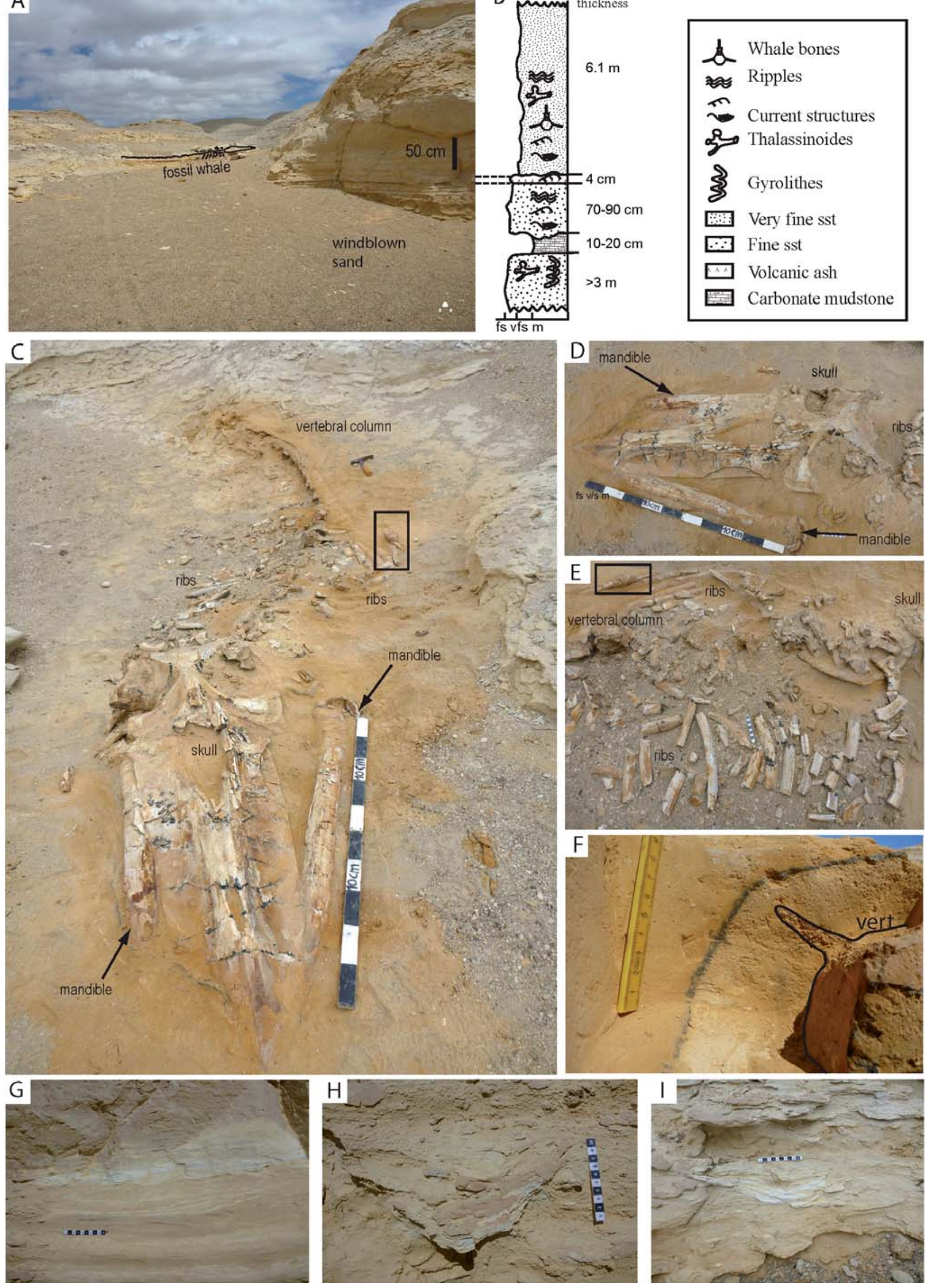
weathering, abrasion, corrosion, fragmentation, predation or scavenging. The uncovered bones show excellent preservation in both the upper and lower surfaces of the bones. No shark tooth marks or any other evidence of predation or scavenging occur in the bones.

\subsubsection{Sedimentology}

The specimen is preserved in a single very thick layer of very fine sandstone that is faintly thinly bedded with abundant ripple-cross lamination, gutter casts, and channel and scour-and-fill structures indicating water currents (Figs 3B, G-I). Thalasinoides and Gyrolithes burrows occur scattered throughout the thickness of the layer. Sediment associated with the bones is reddish, possibly due to the oxidation of minerals during decay of organic matter, and a very thin $(1 \mathrm{~cm})$ rim of black sediment consisting of manganese oxide occurs a few centimeters from the bones (Fig. 3F). No evidence of associated invertebrate fauna on the bones or in the associated sediment was found. The sediments underlying the layer with the whale skeleton consist of, from top to bottom, a thin layer of ripple crosslaminated white volcanic ash $(1-4 \mathrm{~cm})$, a thinly bedded, fine-grained sandstone, a thin layer of carbonate-cemented mudstone, and a very thick layer of fine-grained sandstone with Gyrolithes and Thalassinoides burrows, especially abundant in the top fifty centimeters (Fig. 3B). These features conform to a shallow, well oxygenated to brackish water nearshore environment with storm influence.

\subsubsection{Paleopathology}

One of the ribs of this whale shows evidence of a healed fracture (Figs 3C, E, 4). The cross-section of the bone shows that the endosteal bone growth covers and surrounds the entire fracture area, thus indicating that the injury occurred in life. The fracture displaced both broken ends in an oblique pattern to the long axis of the shaft, with $21 \%$ displacement of the shaft and $15 \%$ angulation. Displacement is calculated by dividing a/b in Figure 4C. Displacement is typically described in orthopedic literature as a percentage of the width of the bone, and angulation as the angle measured at the intersection of the lines of the shaft long axis of adjacent segments of bone. A fracture that is non-displaced and non-angulated would have the fragments lined up with zero angulation as the shaft long axis of each side of the fracture would be on the same line. A fracture that is displaced but not angulated would have the longitudinal axis lines parallel. The separation between the parallel lines of the shaft axis divided by the width of the bone at the fracture site yields the percentage of displacement. Figure $4 \mathrm{C}$ shows that the ends of the
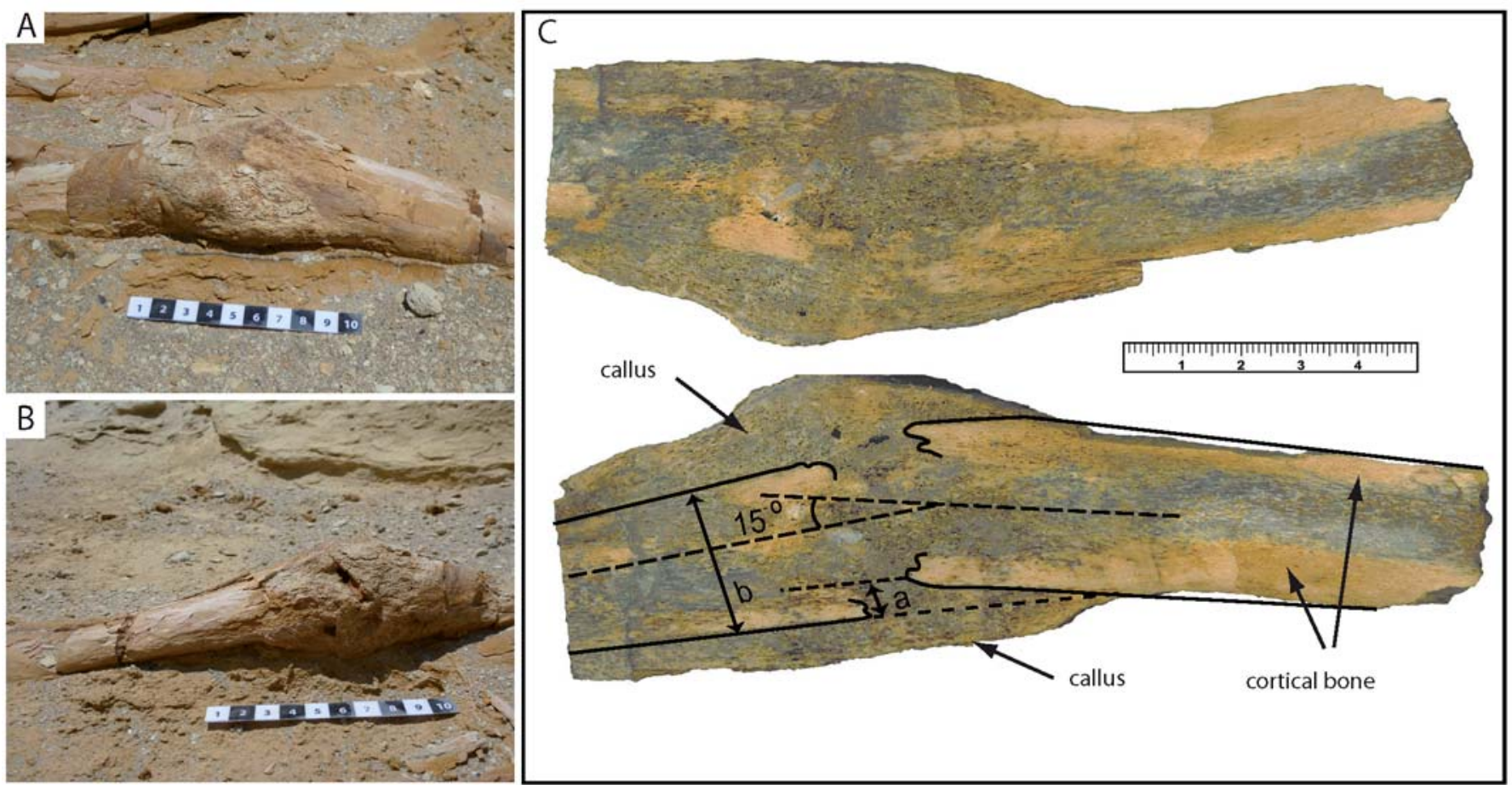

Figure 4. Detail of the healed broken rib of whale AM13-1. A-B). The bone as it was found in the field attached to the underlying rock. C) Longitudinal cross-section of the rib showing the fracture. The cortical bone in the shaft shows a separation of 0.8-1.5 cm, and an angularity of $15^{\circ}$. A thick callus developed that healed the fracture before realignment of the shaft. See the main text for explanations. Scale bars in $\mathrm{cm}$. Rectangles in C) and E) indicate the fractured rib. 
fractured shaft never united and the two fragments remained displaced a distance of 1-1.5 centimeters. The bony callus and displacement due to the fracture caused an increase in the thickness of the bone from $29 \mathrm{~mm}$ of the original healthy rib to $50 \mathrm{~mm}$ in the middle of the fracture area.

\section{DISCUSSION}

\subsection{Articulation and preservation}

The two whale skeletons show a high degree of preservation and articulation. Specimen AM13-1 is almost fully articulated and specimen FP08-12 shows partial disarticulation but with bones nearly in anatomical position. Partial disarticulation is likely not due to displacement by water currents or the activity of scavengers, but to the collapse of the skeletons after decay of the connective tissue. The bones are uniformly well preserved. There is no difference in degree of preservation between long and short bones, flat or rounded bones, or between small and large bones. Both the upper and lower surfaces of the bones (e.g., vertebrae, skull) show the same degree of excellent preservation, except for partial weathering of some bones due to modern exposure. This contrasts with the bones of some recent carcasses on the seafloor, which show differential preservation, with lower surfaces in contact with sediment or partially buried bones showing better preservation than exposed upper surfaces or fully exposed bones (Allison et al., 1991; Esperante, 2005; Fujiwara et al., 2007).

Corrosion (i.e., destruction of bones by chemical reaction with water, which commonly results in the removal of the cortical bone and exposure of the underlying cancellous bone) and abrasion (i.e., erosion of bone by friction and impact of particles transported by water currents) are common in several shallowwater assemblages, both in ancient and modern settings. Esperante et al. (2009) describe a mysticete fossil from the lower Pliocene Huelva Sands Formation, Spain, with complete lack of cortical bony tissue, most likely due to corrosion and/or abrasion. Dominici et al. (2009) report a large skeleton of a mysticete whale with heavy corrosion and exposure of the fragile cancellous bone, missing thoracic vertebrae and corroded skull possibly due to a prolonged exposure and destruction by bone-eating worms (Osedax) present on the seafloor. Liebig et al. (2007) and Esperante (2004, pers. observ.), note that marine mammal bones in the upper intertidal zone of the Colorado River Delta break down due to corrosion and abrasion, with denser (teeth and ear bones) and larger bones (skulls), and also bones of adults, better represented and preserved. In addition to published studies of in situ specimens, we have examined many unreported marine mammals specimens collected from Pliocene and Miocene shallow-water sediments and stored in the Los Angeles County Museum of Natural History, and their bones show heavy corrosion and abrasion (Esperante, 2008, pers. observ.). In contrast with these assemblages, whales FP08-12 and AM13-1 do not show any evidence of corrosion or abrasion and the surficial cortical bone is well preserved throughout the skeletons, except for those parts that have been weathered in modern times.

\subsection{Associated fauna and scavenging}

Studies of modern whale skeletons in both shallowand deep-water settings show association of diverse and abundant invertebrate fauna. Bennett et al. (1994), and Smith and Baco (2003) proposed that deep-water whale-fall communities follow four successive stages, named 'mobile-scavenger' or 'necrophage' stage, where scavengers remove soft tissue; 'enrichment-opportunist' stage, characterized by the scavenging activity of polychaetes and crustaceans attracted to the carcass by the organic-rich sediments; 'sulphophilic' stage, in which a chemoautotroph community is established; and 'reef' stage, where suspension-feeder macro-invertebrates settled in the associated sediments and remaining bones. Thus the bones of modern whale-falls show heavy deterioration due to scavenging by both macro- and micro-invertebrates and vertebrates, including borings by Osedax worms, and removal of bone tissue by crabs, echinoderms, and other organisms (Allison et al., 1991; Bonfiglio et al., 1996; Smith \& Baco, 2003; Esperante, 2005; Glover et al., 2005; Fujiwara et al., 2007). Dahlgren et al. (2006) carried out a shallow-water whale-fall experiment in which they sank a Minke whale (at $125 \mathrm{~m}$ ) and a Pilot whale (at $30 \mathrm{~m}$ ) in the North Atlantic. Dense populations of amphipods were observed growing and reproducing on exposed bones after 5 weeks and lasting several months. Nine months after deployment of the skeleton, recovered bones were riddled with Osedax worms. Bones of the Pilot whale (at $30 \mathrm{~m}$ depth) remained intact after seven months showing no evidence of scavenging, except those that were already exposed at implantation, which were heavily colonized by Osedax worms. This is significant because it indicates that Osedax are able to colonize whale bones soon after they become exposed (after soft tissue has been removed) even in shallow water settings $(30 \mathrm{~m})$. Dahlgren et al. (2006) concluded that whale-falls can sustain an obligated fauna even at shallow depths, an observation also supported by others (see Glover et al., 2005; Haag, 2005). Fujiwara et al. (2007) report dense biological assemblages consisting of mytilid mussels, other symbiotic-harboring bivalves, Osedax polychaete worms, and numerous other kinds of 
invertebrates associated with six sperm whale carcasses only 1.5 years after deployment of the dead bodies onto the shallow (200-254 m) seafloor off Kyushu Island, Japan. Density of the bivalve Adipicola pacifica attached onto the whale bones was more than 100,000 individuals per $\mathrm{m}^{2}$. Most mollusks covered the surfaces exposed to seawater, but some species (Adipicola crypta, Solemya pervernicosa) were exclusively attached onto the surfaces buried in the sediment. Also this study shows that after 2.5 years of the initial deployment (February 2003-July 2004) of the dead whales the lower halves of the vertebrae were mostly buried in the sediment, their neural processes had nearly disappeared, and the skull had broken down considerably.

Osedax worm-like structures have been observed in several whale fossil assemblages in the Mediterranean and Pacific regions. Kiel et al. (2010) found traces attributed to the bone-eating Osedax in early Oligocene whale bones preserved in deep-water sediment concretions in northwestern Washington State. Muñiz et al. (2010) describe very thin borings in a fragment of neurocranium of a baleen whale from a Pliocene shallow-water sandstone in Almería, southern Spain. They note that the size and shape of the borings (which they named Trypanites ionasi isp. n.) are very similar to those made by modern Osedax worms.

Schuller et al. (2004), using their own developed radiochemical method based on ${ }^{210} \mathrm{~Pb} / 226 \mathrm{Ra}$ disequilibria, suggested that some deep-water whale-fall assemblages could sustain life for many decades. However, other reports of modern deep- and shallow-water whale-falls show a rapid ecological succession of the community stages in less than three years (Esperante, 2005; Fujiwara et al., 2007), and rapid destruction of the entire skeleton in less than a decade (Esperante, 2005). This has been demonstrated by a time-series study of six whale-falls in Monterey Canyon, California, where whale carcasses are shown to undergo almost complete destruction in a period of less than six years, with heavy deterioration within the first year of exposure on the seafloor (Lundsten et al., 2010a). Also, this study and another study of a whale carcass near Vancouver Island, Canada (Lundsten et al., 2010b), have questioned the four-stage model of community succession associated with whale-falls, since some of the stages seem to be missing due to quick decay of the skeletons.

A diverse vertebrate and invertebrate fauna has been found also in association with several fossil marine vertebrate assemblages. Lancaster (1986) describes an almost complete skeleton of a Basilosaurus from deepwater sediments of the upper Eocene Tullos Member of the Yazzo Clay in Alabama that has abundant and diverse invertebrate fauna (gastropods, bivalves, cirripeds, decapods, etc.). Goedert et al. (1995) report fossil mollusks associated with eight Oligocene whales from the deepwater Makah and Pysht Formations on the northwestern part of the Olympic Peninsula, Washington. Amano \& Little (2005) describe fragments of whale bones from
Miocene deep-water sediments in Hokkaido, Japan, preserved with bivalves and gastropods. Amano et al. (2007) describe a fossil whale-fall community from the Miocene Nupinai Formation in Japan consisting of toothed whale bones and associated gastropods and disarticulated bivalves, preserved in sediments interpreted as upper bathyal or lower sublittoral. Dominici et al. (2009) describe an almost complete large mysticete whale from Pliocene shelf deposits of Italy with a diverse fauna of spatangoid echinoderms, large decapods and bivalves. Esperante et al. (2009) report an incomplete whale skeleton with associated bivalves and gastropods preserved in glauconitic sandstone sediments deposited in a shallow shelf $(30-50 \mathrm{~m})$. Muñiz et al. (2011) present evidence of a reef stage associated with a whale skeleton in the lower Pliocene of Huelva, SW Spain.

If the studied Pisco Formation whales had been exposed on the seafloor for many years, we would expect to see at least one of the four stages of decay observed in modern whale-falls. We would expect to see trace evidence of scavenging, consisting of borings by polychaetes worms and bone destruction by crustaceans, echinoderms and mollusks. We would also expect to find fossils of some of those organisms that could have colonized the decaying carcasses and the associated sediment. Finally, the associated sediment should preserve evidence of bioturbation produced by some of the organisms that settle in the organically enriched sea bottom. However, the two studied Pisco whales show no evidence of the decaying stages, associated invertebrate or vertebrate fauna (other than fish scales in the sediment), bioerosion, or scavenging. Bioturbation occurs only in the sediment associated with whale AM13-1.

We exclude anoxia as the cause of the excellent preservation of these bones. Whale AM13-1 occurs in sediment containing ichnofossils and sedimentary structures that indicate water current, wave action and water mixing in a well oxygenated shallow setting. Whale FP08-12 occurs in fine diatomaceous sediment that lacks visible sedimentary structures associated with the skeleton, except for lenticular laminations of diatom-rich musdstone. However, sedimentary structures indicative of water currents and high-energy events are present in the diatomaceous layers of the Pisco Formation, including the section where this skeleton occurs. These structures include channel and scour-and-fill structures, and ripples. Also, the diatomaceous units contain scattered but abundant oval- to elongate-shaped concretions of yellow to reddish sandstone often with pebble conglomerates at the bottom, which indicate high-energy events that transported coarser sediment from shallower depths and possibly the foreshore. Moreover, the study of recent cetacean carcasses on lowoxygen or anoxic sea bottom shows that decay, scavenging and destruction of the bones occurs quickly, in a period of a few months to less than a decade, and that complete 
destruction occurs before preservation by burial may happen (Allison et al., 1991; Esperante, 2005; Lundsten et al., 2010a, b).

\subsection{Burial}

The uniform degree of preservation of all the bones of the fossil specimens and the lack of evidence for long time exposure on the seafloor or macro-scavenging before burial suggest that the two skeletons were rapidly buried after the soft tissue was removed and before any vertebrates and/or invertebrates could scavenge on the bones. If the carcasses had been buried before removal of soft tissue the associated sediment would show evidence of deformation due to collapse after decay of the soft tissue. However, the sediment shows no evidence of deformation due to collapse or compression. The sediment exposed in two trenches perpendicular to the skeleton shows no evidence of sediment collapse or any other feature that would suggest that the whale sank into a very soft ground. The lenticular laminations of the diatomaceous mudstone reach the bone surface or are slightly bent over its top surface. This feature is very conspicuous in the sediment associated with whale FP08-12 (Fig. 3F), and it is less evident in the trench excavated at whale AM13-1.

Preservation of whale FP08-12 in very fine sediment (diatomaceous mudstone) suggests that the whale carcass was buried in a neritic setting near the outer shelf with a high degree rate of mud and diatom accumulation. The occurrence of sedimentary structures in the diatomaceous sequence indicative of water currents and agitation suggests that the environment was well oxygenated. Whale AM13-1 is also well preserved, and occurs in a layer of siltstone with abundant sedimentary structures indicative of water currents and agitation. The bones of this specimen should show disarticulation, abrasion and corrosion, and yet they are well preserved and only show disarticulation of the skull from the vertebral column. This excellent degree of articulation and preservation in both studied specimens is not expected if they lay on the seafloor for an extended period of time before burial, as in the case in most modern whale-falls.

\subsection{Paleopathology}

The rib fractures found in both specimens are complete, i.e. the bone fragments separated completely. The ribs show angularity of the two portions of the shaft after fracturing and callus development during healing (Figs 2, 3). In whale AM13-1, the fracture site is surrounded by clearly defined hypertrophic callus of woven bone that has united the fractured shaft; however, the original cortices are clearly seen indicating the stage of healing is intermediate without cortical remodeling. The relatively porous and woven structure of the callus is clearly seen and contrasts with the denser highly lamellar structure of the normal cortex in this fossil just as it would in a non-fossilized fresh bone (Fig. 4C). The hypertrophic callus formation around the fracture line of the healed rib of AM13-1 indicates that the whale survived the lesion, though the incomplete remodeling of the cortex indicates that the whale died a few months after the injury. This also might be the case with the other specimen, whale FP08-12, but no crosssection of the fractured rib was made to verify it.

Reported causes of bone fractures in both marine and terrestrial vertebrates include accidents, predation (biting), the performance of strenuous or repetitive activities, aggressive behavior, pathology (degenerative arthritis and osteoporosis are the most common cause of pathological fracture), and other intra- and interspecies interactions (Sawyer \& Erickson, 1987; Rothschild \& Tanke, 1992). Predation may cause bone fracture but also the death of the individual and thus no opportunity for healing. Stress fractures result from the overstressing of the mechanical properties of the bone during some strenuous activity, and have been recognized in proximal phalanges of several species of dinosaurs (Rothschild, 1988; Rothschild et al., 2001). Aggressive behavior like fighting may result in multiple bone fractures, and can also be fatal, but some specimens have been reported with healed fractures that underwent bone modification indicative of healing (Sawyer \& Erickson, 1987; Lingham-Soliar, 2004). Additionally, Ogden et al. (1981) report a naturally-occurring fracture of the distal radius and ulna in a skeletally immature fin whale (Balaenoptera physalus), in which no healing occurred.

Some possible causes for the fractures in the studied fossil whales may include 1) osteoarthritis; 2) intraspecific and interspecific interactions including play, competition, adult-juvenile interactions, and attacks by sharks or other large predators; and 3) collision with rocky shores. Osteoarthritis occurs in joints and would not cause breakage of the shaft of a rib. We rule out shark attacks as the cause of the fractures of the bones because a shark attack would most likely be fatal to the whale, with no time to heal the fracture. In order to break a rib a shark would have to inflict a large wound into the body of the whale. Several shark teeth have been found in association with the FP08-12 skeleton, but not with the AM13-1 skeleton, although the latter is partially exposed on the ground, which might explain the absence of teeth due to removal by recent erosion. Despite the occurrence of shark teeth associated with one specimen, the two whale specimens described here lack any evidence of an attack by a shark or any other predator. Also, there is a general absence of shark tooth marks on whale bones in the Pisco Formation. Several hundred specimens of baleen whales and other marine organisms have been studied in the Pisco Formation by our team, and shark teeth are relatively common in 
association with the skeletons (Esperante, 2002). Despite the abundance of shark teeth, only two whale specimens have been found with shark tooth marks on bones. The generalized absence of shark tooth marks on bones in the Pisco Formation is puzzling given the abundance of shark teeth associated with the skeletons. A possible predator has been documented in sediments of the middle Pisco Formation, consisting of a new species of giant sperm whale (Livyatan melvillei) (Lambert et al., 2010), which occurs in a layer that is roughly correlatable with specimen AM13-1 described here. The cause of death of the two whales is unknown, but it is unrelated to the fracturedbones, because the fractures healed during the lifetimes of the organisms.

Bone fractures could have been the result of intraor inter-specific interactions, including play, aggressive behavior, or hitting a rocky shore (as suggested by Thomas et al., 2008). There is evidence of rocky shores in the Pisco Basin consisting of pre-Cenozoic igneous basement that was partially exposed subaerially during the deposition of the sediments in the basin. It is known that males of many species of cetaceans, especially those in which there exists sexual dimorphism, engage in physical aggression during intrasexual competition (Campagna, 2002; Tyack \& Whitehead, 2002). Baker \& Herman (1984) document charge-strikes as a characteristic behavior associated with aggression between humpback whales (Megaptera novaeangliae). Numerous cases of aggressive behavior by killer whales (Orcinus orca) are documented by Ford \& Reeves (2008), including charges and jumping of killer whales onto mysticete individuals. Thus we suggest that the cause of bone fracture in the two whale fossil specimens studied may have been collision with rocky shores and/ or other whales or aggressive behavior by predators. The high abundance of individual whales within the basin (Esperante, 2002) would have increased the likelihood of aggressive, competitive behavior, or bumping into one another, thus causing fractures in ribs.

\section{CONCLUSIONS}

Two specimens of fossil Mysticete from the Miocene Pisco Formation in Peru were excavated to study their taphonomy. Compared to modern whale carcasses on the seafloor, which undergo quick destruction by scavengers and removal and/or displacement of bones by water currents before burial may occur, these two fossil whale skeletons are mostly articulated, and show an excellent degree of preservation, with no evidence of erosion, abrasion orscavenging by micro- or macro-fauna. No associated fauna was found, except for a few shark teeth associated with specimen FP08-12. No shark tooth marks were observed on the bones. The excellent degree of preservation, articulation and completeness of the two fossil specimens indicates that reworking of the skeletons or long exposure on the seafloor after death did not occur. Sedimentologic and paleontological evidence suggests that the two whale skeletons were quickly buried in a welloxygenated marine platform of the Pisco Basin after their soft tissue was removed and before scavenging of the bones and extensive disarticulation could occur. The type of deposits and sedimentary structures indicate that whale AM13-1 was buried in an environment of shallow water, but not on the beach, whereas whale FP08-12 was buried in an offshore, deeper environment with storm influence. We suggest that the rate of sedimentation during burial of these two whale skeletons in the Pisco Basin must have been very high compared with similar modern shallow marine settings where fine sediment is being deposited.

Both specimens display a healed broken rib. Fractures affected the respective shafts of the ribs and caused angular displacement, with subsequent healing through the formation of a callus. The fractures did not cause the death of the whales. We conclude that collision with another large animal or with a rocky shore might have caused the fractures.

\section{ACKOWLEDGMENTS}

We thank the Geoscience Research Institute and Universidad Peruana Unión for generous grants to carry out this research. We thank Dr. Ronald Ghazal of Arrowhead Orthopaedics, and Dr. Barry Watkins of Loma Linda University Hospital for useful insights in the interpretation of the bone fractures. We appreciate the help of two anonymous reviewers that commented on an early version of the paper.

\section{REFERENCES}

Allison, P.A., Smith, C.R., Kukert, H., Deming, J.W. \& Bennet, B.A. 1991. Deep-water taphonomy of vertebrate carcasses: a whale skeleton in the bathyal Santa Catalina Basin. Paleobiology, 17, 78-89.

Amano, K. \& Little, C.T.S. 2005. Miocene whalefall community from Hokkaido, northern Japan. Palaeogeography, Palaeoclimatology, Palaeoecology, 215, 345-356.

Amano, K., Little, C.T.S. \& Inoue, K. 2007.A new Miocene whale-fall community from Japan. Palaeogeography, Palaeoclimatology, Palaeoecology, 247, 236-242.

Baker, C.S. \& Herman, L.M. 1984. Aggressive behavior between humpback whales (Megaptera novaeangliae) 
wintering in Hawaiian waters. Canadian Journal of Zoology, 62, 1922-1937.

Beatty, B.L. \& Dooley, A.C. 2009. Injuries in a mysticete skeleton from the Miocene of Virginia, with a discussion of buoyancy and the primitive feeding mode in the Chaeomysticeti. Jeffersoniana, 20, 1-32.

Bennet, B.A., Smith, C.R., Glaser, B. \& Maybaum, H.L. 1994. Faunal community structure of a chemoautotrophic assemblage on whale bones in the deep northeast Pacific Ocean. Marine Ecology Progress Series, 108, 205-223.

Bonfiglio, L., Crucitti, R., Insacco, G., Marra, A.C. \& Muscolino, M. 1996. Discovery of a partially articulated whale skeleton from Pliocene intertidal sands of Calabria (southern Italy), In: II Reunión de Tafonomía y Fosilización (eds. Meléndez Hevia, G., Blasco Sancho, M.F. \& Pérez Urresti, I. (Eds.). CSIC, Zaragoza, p. 61-66.

Campagna, C. 2002. Aggressive behavior (intraspecific). In: Encyclopedia of marine mammals (eds. Perrin, W.F., Würsig, B. \& Thewissen, G.M.J.). Academic Press, San Diego, 13-16.

Cartmill, M. \& Smith, F.H. 2009. The human lineage. WileyBlackwell, New Jersey.

Carvajal, C., Buchheim, H.P., Poma, O., Chadwick, A. \& Brand, L. 2000. Sedimentology and paleoenvironment of whale bearing sediments of the Miocene/Pliocene Pisco Formation, Peru. Geological Society of America Annual Meeting Abstract book, p. A10.

Carvajal, C.R. 2002. Sedimentology and paleoenvironments of the Miocene/Pliocene Pisco Fm., Perú. PhD Thesis, Loma Linda University, Loma Linda (unpublished).

Cowan, D. 1966. Pathology of the pilot whale. Globicephala melaena. A comparative survey. Archives of Pathology, 82, 178-189.

Dahlgreen, T.G., Wiklund, H., Kallstrom, B., Lundalv, T., Smith, C.R. \& Glover, A.G. 2006. A shallow-water whalefall experiment in the north Atlantic. Cahiers Biologie Marine, 47, 385-389.

Dawson, S.D. \& Gottfried, M.D. 2002. Paleopathology in a Miocene kentriodontid dolphin (Cetacea, Odontoceti). Smithsonian Contributions to Paleobiology, 93, 263-270.

DeVries, T.J. 1998. Oligocene deposition and Cenozoic sequence boundaries in the Pisco Basin (Peru). Journal of South American Earth Sciences, 11, 217-231.

de Muizon, C. \& DeVries, T.J. 1985. Geology and paleontology of late Cenozoic marine deposits in the Sacaco area (Peru). Geologische Rundschau, 74, 547-563.

Dominici, S., Cioppi, E., Danise, S., Betocchi, U., Gallai, G., Tangocci, F., Valleri, G. \& Monechi, S. 2009. Mediterranean fossil whale falls and the adaptation of mollusks to extreme habitats. Geology, 37, 815-818.

Dunbar, R.B., Marty, R.C. \& Baker, P.A. 1990. Cenozoic marine sedimentation in the Sechura and Pisco basins, Peru. Palaeogeography, Palaeoclimatology, Palaeoecology, 77, 235-261.

Esperante, R. 2002. Taphonomy of fossil whales in diatomaceous sediments of the NeogenePisco Formation, Peru. PhD Thesis, Loma Linda University, Loma Linda (unpublished).
Esperante, R. 2005. How not to become a fossil-Taphonomy of modern whale falls. In: 2nd International Meeting TAPHOS'05 (eds. Martinell, J., Domènech, R. \& de Gibert, J.M.). Universitat de Barcelona, p. 103-104.

Esperante, R., Brand, L.R., Chadwick, A. \& Poma, O. 2002. Taphonomy of fossil whales in the diatomaceous sediments of the Miocene/Pliocene Pisco Formation, Peru.In: Current Topics on Taphonomy (eds. De Renzi, M., Pardo Alonso, M.V., Belinchón, M., Peñalver, E., Montoya, P. \& Márquez-Aliaga, A.). Ayuntamiento de Valencia, p. 337-343.

Esperante, R., Muñiz Guinea, F. \& Nick, K.E. 2009. Taphonomy of a Mysticeti whale in the Lower Pliocene Huelva Sands Formation (Southern Spain). Geologica Acta, 7, 489-505.

Ford, J.K.B. \& Reeves, R.R. 2008. Fight or flight: antipredator strategies of baleen whales. Mammal Review, 38, 50-86.

Fujiwara, Y., Kawato, M., Yamamoto, T., Yamanaka, T., SatoOkoshi, W., Noda, C., Tsuchida, S., Komai, T., Cubelio, S.S. \& Sasaki, T. 2007. Three-year investigations into sperm whale-fall ecosystems in Japan. Marine Ecology, 28, 219-232.

Gerholdt, J.M. \& Godfrey, S.J. 2010. Enigmatic osteology in Miocene odontocete rostra suggests periostitis. Marine Mammal Science, 26, 381-394. doi: 10.1111/j.17487692.2009.00342.x

Glover, A.G., Kallstrom, B., Smith, C.R. \& Dahlgreen, T.G. 2005. World-wide whale worms? A new species of Osedax from the shallow north Atlantic. Proceedings of the Royal Society B, 272, 2537-2592.

Godfrey, S.J. \& Altman, J. 2005. A Miocene cetacean vertebra showing a partially healed compression fracture, the result of convulsions or failed predation by the giant white shark, Carcharodon megalodon. Jeffersoniana, 16, 1-12.

Goedert, J.L., Squires, R.L. \& Barnes, L.G. 1995. Paleoecology of whale-fall habitats from deep-water Oligocene rocks, Olympic Peninsula, Washington State. Palaeogeography, Palaeoclimatology, Palaeoecology, 118, 151-158.

Govean, F.M. \& Garrison, R.E. 1981. Significance of laminated and massive diatomites in the upper part of the Monterey Formation, California. In: The Monterey Formation and related siliceous rocks of California (eds. Garrison, R.E. \& Douglas, R.E.). Society of Economic Paleontologists and Mineralogists, Pacific Section, Los Angeles, California, 181-198.

Haag, A. 2005. Marine biology: whale fall. Nature, 433, 566-567.

Katsura, Y. 2004. Paleopathology of Toyotamaphimeia machikanensis (Diapsida, Crocodylia) from the Middle Pleistocene of Central Japan. Historical Biology, 16, 93-97.

Ketten, D.R. 2005. Beaked whale necropsy findings for strandings in the Bahamas, Puerto Rico, and Madeira, 1999-2002. Woods Hole Oceanographic Institution Technical Report WHOI-2005-09, p. 34.

Kiel, S., Goedert, J.L., Kahl, W.A. \& Rouse, G.W. 2010. Fossil traces of the bone-eating worm Osedax in early Oligocene whale bones. Proceedings of the National Academy of Sciences, 107, 8656-8659. 
Kompanje, E.J.O. 1999. Considerations on the comparative pathology of the vertebrae in Mysticeti and Odontoceti; evidence for the occurrence of discarthrosis, zygarthrosis, infectious spondylitis and spondyloarthritis. Zoologische Mededelingen, 73, 99-130.

Lambert, O., Bianucci, G., Post, K., de Muizon, C., SalasGismondi, R., Urbina, M. \& Reumer, J. 2010. The giant bite of a new raptorial sperm whale from the Miocene epoch of Peru. Nature, 466, 105-108.

Lancaster, W.C. 1986. The taphonomy of an Archaeocete skeleton and its associated fauna, In: 36th Symposium Montgomery Landing Site, Marine Eocene (Jackson) of Central Louisiana (eds. Schiebout, J.A. \& Bold, W.V.D.). Gulf Coast Association of Geological Societies, Baton Rouge, Louisiana, p. 119-131.

Liebig, P.M., Flessa, K.W. \& Taylor, T.-S.A. 2007. Taphonomic variation despite catastrophic mortality; analysis of a mass stranding of false killer whales (Pseudorca crassidens), Gulf of California, Mexico. Palaios, 22, 384-391.

Lingham-Soliar, T. 2004. Paleopathology and injury in the extinct mosasaurs (Lepidosauromorpha, Squamata) and implications for modern reptiles. Lethaia, 37, 255-262.

Lordkipanidze, D., Ponce de León, M.S., Margvelashvili, A., Rak, Y., Rightmire, G.P., Vekua, A. \& Zollikofer, C.P.E. 2013. A complete skull from Dmanisi, Georgia, and the evolutionary biology of early Homo. Science, 342, 326-331.

Lundsten, L., Schlining, K.L., Frasier, K., Johnson, S.B., Kuhnz, L.A., Harvey, J.B., Clague, G. \& Vrijenhoek, R.C. 2010a. Time-series analysis of six whale-fall communities in Monterey Canyon, California, USA. Deep Sea Research Part I: Oceanographic Research Papers, 57, 1573-1584.

Lundsten, L., Paul, C.K., Schlining, K.L., McGann, M. \& Ussler III, W. 2010b. Biological characterization of a whale-fall near Vancouver Island, British Columbia, Canada. Deep Sea Research Part I: Oceanographic Research Papers, 57, 918-922.

Marty, R. 1989. Stratigraphy and chemical sedimentology of Cenozoic biogenic sediments from the Pisco and Sechura Basins, Peru. PhD Thesis, Rice University, Houston (unpublished).

Marty, R.C., Dunbar, R.B., Allen, M.R., Baker, P.A. \& Martin, J.B. 1987. Tertiary diatomite distribution in the Pisco Basin, Peru. Geological Society of America Annual Meeting, Abstracts book, p. 761-762.

Molnar, R.E. 2001. Theropod paleopathology; a literature review. In: Mesozoic vertebrate life; new research inspired by the paleontology of Phillip J. Currie (eds. Tanke, D.H., Carpenter, K. \& Skrepnick, M.W.). Indiana University Press. p. 337-363.

Muñiz, F., Gibert, J.M. de \& Esperante, R. 2010. First tracefossil evidence of bone-eating worms in whale carcasses. Palaios, 25, 269-273.

Muñiz, F., Esperante, R. \& Nick, K.E. 2011. Evidence of a reef stage associated with a whale skeleton in the lower Pliocene of Huelva, SW Spain, In: 6th International Meeting on Taphonomy and Fossilization-Taphos (eds. Nebelsick, J.H., Friedrich, J.-P. \& Dynowski, J.), p. 54-55.
Ogden, J.A., Conlogue, G.J., Light, T.R. \& Sloan, T. 1981. Fractures of the radius and ulna in a skeletally immature fin whale. Journal of Wildlife Diseases, 17, 111-116.

Oremland, M.S., Allen, B.M., Clapham, P.J., Moore, M.J., Potter, C. \& Mead, J.G. 2010. Mandibular fractures in short-finned pilot whales, Globicephala macrorhynchus. Marine Mammal Science, 26, 1-16.

Rothschild, B.M. 1988. Stress fracture in a ceratopsian phalanx. Journal of Paleontology, 62, 302-303.

Rothschild, B.M. \& Tanke, D. 1992. Paleopathology of Vertebrates: Insights to Lifestyle and Health in the Geological Record. Geoscience Canada, 19, 73-82.

Rothschild, B., Tanke, D.H. \& Ford, T.L. 2001. Theropod stress fractures and tendon avulsions as a clue to activity. In: Mesozoic vertebrate life (eds. Tanke, D., Carpenter, K. \& Skrepnick, M.W.). Indiana University Press, Bloomington, Indiana, 331-336.

Rothschild, B. \& Molnar, R.E. 2005. Sauropod stress fractures as clues to activity. In: Thunder-lizards: the sauropodomorphs dinosaurs (eds. Tidwell, V. \& Carpenter, K.). Indiana University Press, Bloomington, Indiana, 381-392.

Sawyer, G.T. \& Erickson, B.R. 1987. Injury and disease in fossil animals. Bulletin of the Field Museum of Natural History, 58, 20-25.

Sawyer, G.T. \& Erickson, B.R. 1998. Paleopathology of the Paleocene crocodile Leidyosuchus. Science Museum of Minnesota, St. Paul, Minnesota.

Schuller, D., Kadko, D. \& Smith, C.R. 2004. Use of $210 \mathrm{~Pb} / 226 \mathrm{Ra}$ disequilibria in the dating of deep-sea whale falls. Earth and Planetary Science Letters, 218, 277-289.

Smith, C.R. \& Baco, A.R. 2003. Ecology of whale falls at the deep-sea floor. Oceanography and Marine Biology: An Annual Review, 41, 311-354.

Straight, W.H., Skinner, H., Catherine, W., Haims, A., McClennan, B.L., Davis, G.L. \& Patrick, D. 2006. Injury and recovery in dinosaurs; radiology and geochemistry of pathologies in hadrosaur bones. Geological Society of America, Northeastern Section, 41st Annual Meeting, Abstract Book, p. 22-23.

Tanke, D.H. \& Currie, P.J. 1998. Head-biting behavior in theropod dinosaurs: paleopathological evidence. Gaia, $15,167-184$

Thomas, H.W., Barnes, L.G., Klein, J.E. \& McLeod, S.A. 2008. Examples of paleopathologies in some fossil Cetacea from the North Pacific realm. Natural History Museum of Los Angeles County Science Series, 41, 153-179.

Tyack, P.L. \& Whitehead, H. 2002. Male competition in large groups of wintering humpback whales. Behaviour, $83,132-154$.

Uhen, M.D. 2004. Form, function, and anatomy of Durodonatrox (Mammalia, Cetacea): An Archaeocete from the Middle to Late Eocene of Egypt. University of Michigan Papers on Palentology, 34, 1-222.

Young, F.B. \& Cooper, A.L. 1927. A study in paleopathology. Radiology, 8, 230-240. 